\title{
Determination of NPS Fertilizer Rate Based on Calibrated Phosphorus for Yield of Bread Wheat in Wachale District, North Shewa Zone, Oromia, Ethiopia
}

\author{
Abera Donis ", Dejene Getahun, Tadele Geremu, Dereje Girma, Abreham Feyisa, Lello Dejene, \\ Meron Tolosa
}

Oromia Agricultural Research Institute, Fitche Agricultural Research Center, Oromia, Ethiopia

Email address:

aberadonis2006@gmail.com (A. Donis)

${ }^{*}$ Corresponding author

To cite this article:

Abera Donis, Dejene Getahun, Tadele Geremu, Dereje Girma, Abreham Feyisa, Lello Dejene, Meron Tolosa. Determination of NPS Fertilizer Rate Based on Calibrated Phosphorus for Yield of Bread Wheat in Wachale District, North Shewa Zone, Oromia, Ethiopia. American Journal of Plant Biology. Vol. 6, No. 3, 2021, pp. 73-77. doi: 10.11648/j.ajpb.20210603.15

Received: May 21, 2021; Accepted: July 13, 2021; Published: September 8, 2021

\begin{abstract}
Farmers are using NPS fertilizer rates in the area without any recommendation of crop response to the respective fertilizers This experiment was conducted to evaluate the effect of NPS fertilizer rate for higher yield of bread wheat in Wachale district. The experiment consisted six rates of NPS fertilizer rate supplemented with $92 \mathrm{~kg} \mathrm{~N} \mathrm{ha}^{-1}$ laid out in RCBD with three replications. Improved variety of bread wheat Danda'a was used. The analyzed result indicated that, plant height and wheat grain yield were significantly $(\mathrm{P}<0.05)$ influenced by NPS fertilizer rate. The highest $(94.56 \mathrm{~cm})$ plant height was recorded from the application of $100 \%$ P-critical in NPS fertilizer rate and the lowest $(63.62 \mathrm{~cm})$ plant height was recorded from unfertilized plot. The highest $\left(2833 \mathrm{~kg} \mathrm{ha}^{-1}\right)$ grain yield was obtained from the application of $100 \%$ P-critical in NPS fertilizer rate and the lowest $\left(888 \mathrm{~kg} \mathrm{ha}^{-1}\right)$ grain yield was obtained from unfertilized plot. Partial budget analysis showed that the highest net benefit (53401.51 ETB ha ${ }^{-1}$ ) and marginal rate of return (MRR) (1093.80\%) were obtained from the fertilizer application of $100 \% \mathrm{P}$ critical in NPS fertilizer). Therefore, $100 \%$ equivalent rate of NPS fertilizer rate in relative to determined critical phosphorus supplemented with $92 \mathrm{~kg} \mathrm{~N} \mathrm{ha}^{-1}$ for bread wheat could be recommended and thus soil test based crop response phosphorus fertilizer recommendation with $92 \mathrm{~kg} \mathrm{ha}^{-1}$ of Nitrogen could be demonstrated and further scaled up for Bread wheat in Wachale district.
\end{abstract}

Keywords: Fertilizer, Blanket Recommendation, Soil Test Based, Net Income, Marginal Rate of Return

\section{Introduction}

Cereals are the most widely grown crops and comprise about $87.97 \%$ of total grain production in Ethiopia [6]. Wheat is one of the most important cereals in Ethiopia and it is one of the largest producers of wheat in sub-Saharan Africa. The area coverage and production of the crop in Ethiopia is estimated to be 1.7 million hectares and 4.8 million tons of grain yields, respectively. These accounts about $15.39 \%$ of total grain output in the country [6]. There are two types of wheat grown in Ethiopia: durum and bread wheat accounting 40 and $60 \%$ of production, respectively. Wheat production in Ethiopia are characterized by subsistence farming and mostly dominated by small holder farmers $[6,13]$. The national average productivity of wheat (2.7 tone ha) [6] is still lower than world's average (3.4 tone $\mathrm{ha}^{-1}$ ) [10]. Of the many reason for low productivity of wheat; decline of soil fertility, prevalence of disease, dependency on rain-fed traditional agriculture and low input including fertilizer application are the most important ones.

In order to tackle this soil fertility problem, the Ministry of Agriculture was conducting soil and plant nutrient survey to determine the key soil nutrient limitations along with importation of different blended fertilizers and micronutrients from abroad and test these against Urea $\left(50 \mathrm{~kg} \mathrm{ha}^{-1}\right)$ and di-ammonium phosphate (DAP, $100 \mathrm{~kg} \mathrm{ha}^{-1}$ ) for their impact on crop yield in different areas and crops. The results from both of these initiatives showed deficiency of 3 to 6 
nutrients N, P, S, Zn, Mo and B. In most parts of the country and crops responded to the application of additional nutrient. Moreover, the plant analysis data from the same sites indicated that wheat plants were deficient in $\mathrm{N}, \mathrm{P}, \mathrm{Zn}$ and $\mathrm{K}$ [11]. Due to this, Ethiopia is moving from blanket recommendations for fertilizer application rates to recommendations that are customized based on soil type and crop. This is a move towards diversification and away from DAP and Urea, which have long been the only type of fertilizer imported for grain crops.

The farmers in most parts of the country in general and in the study area in particular have limited information on the impact of different types and rates of fertilizers except blanket recommendation. However, according to the soil fertility map covering over 150 districts, most of the Ethiopian soils lack about seven nutrients $(\mathrm{N}, \mathrm{P}, \mathrm{K}, \mathrm{S}, \mathrm{Cu}, \mathrm{Zn}$ and B) [9]. [2] Reported that grain yield and yield components of wheat $(100 \%)$ fully responded to applied nitrogen, $72.3 \%$ showed response to sulfur, $78 \%$ showed response to applied phosphorus on eighteen fields studied in central high lands of Ethiopia and strongly indicated sulfur deficiency along with its importance to include in balanced fertilizer formula. Apart from blanket recommendation of nitrogen and phosphorus, the effect of other fertilizers on yield and yield components of bread wheat and durum wheat are unknown in Ethiopia, even though new fertilizers such as NPS $\left(19 \% \mathrm{~N}, 38 \% \mathrm{P}_{2} \mathrm{O}_{5}\right.$ and $\left.7 \% \mathrm{~S}\right)$ are currently being used by the farmers with blanket recommendation of $100 \mathrm{~kg}$ NPS $\mathrm{ha}^{-1}$ in Ethiopia.

Since, Ethiopia is moving from blanket recommendations to soil test based fertilizer recommendations, Fitche Agricultural Research Center was conduct a research to determine critical phosphorus concentration and phosphorus requirement factors for bread wheat in Wachale district, North Shewa Zone. However, the effect of NPS fertilizer rate was not determined for bread wheat in the study area. Thus, based on the determined Pc (9.5 ppm) and Pf (14.23), optimum NPS fertilizer rate determination was carried out in the study area with the objectives; to determine NPS fertilizer in relative to determined P-critical for bread wheat and to estimate the economically feasible NPS fertilizer rate for higher yield of bread wheat in Wachale district.

\section{Material and Methods}

\subsection{Description of the Study Area}

The experiment was conducted in Wachale district of North Shewa Zone, Oromia, central high lands of Ethiopia. The district is located at $78 \mathrm{~km}$ of the capital Addis Ababa in the Northwest direction. The district is located between $9^{\circ} 25^{\prime} 2.13^{\prime \prime}$ to $9^{\circ} 48^{\prime} 44^{\prime \prime}$ North and $38^{\circ} 38^{\prime} 49.02^{\prime \prime}$ to $39^{\circ} 08^{\prime} 41^{\prime \prime}$ East. The altitude of the study area ranges between 1200 and 2880 (m.a.s.l). That means the districts have the three major classification of landform such as highland, lowland and midland. The mean annual rainfall of the area is about 1000 $\mathrm{mm}$ that ranges from 1000 to $1800 \mathrm{~mm}$. The maximum and minimum annual temperature is $3^{\circ} \mathrm{C}$ and $25^{\circ} \mathrm{C}$, respectively.

Major farming systems of Wachale district were mixed farming; cereal crop cultivation and livestock rearing. Livestock productions are the most important agricultural activity next to crop production in the district, which supports the traditional subsistence farming of cereal crops. The crops such as wheat, teff, beans, barley, Chickpea, Lentil, Pea etc are the major crop in the study area.

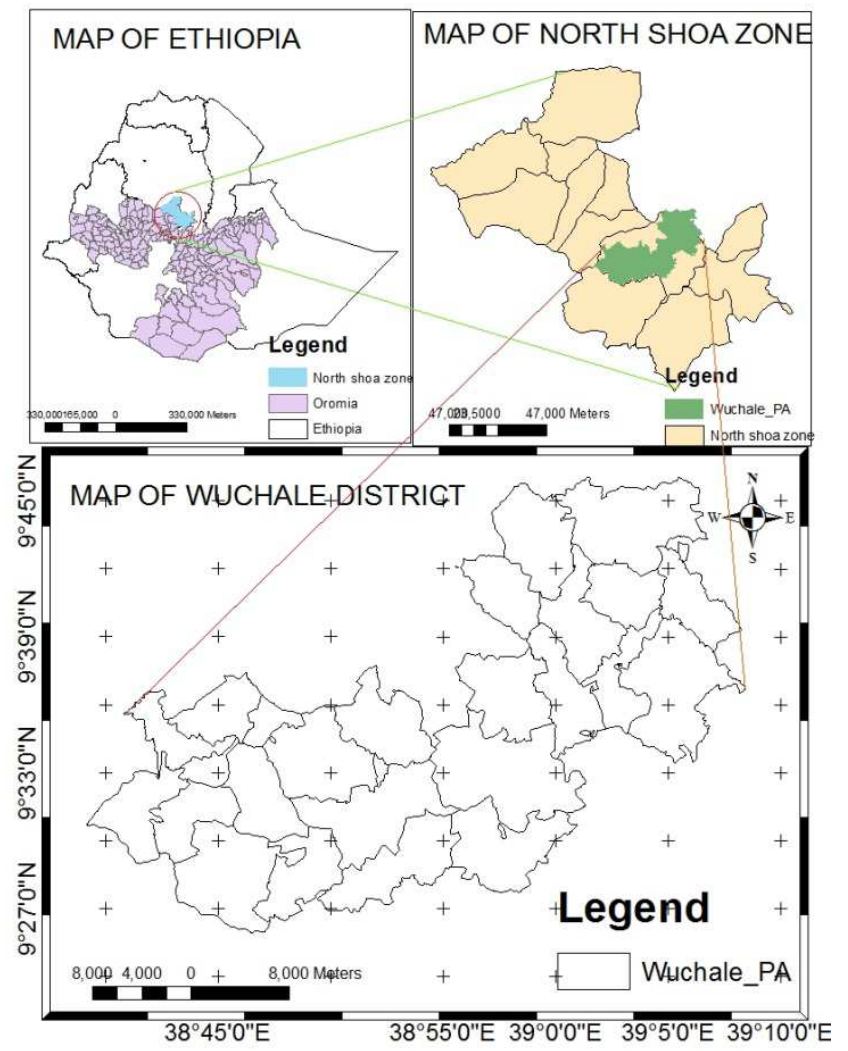

Figure 1. Location map of Wachale district.

\subsection{Site Selection, Soil Sampling and Analysis Methods}

Bread wheat production potential kebeles (small administrative unit) were selected from the district. Accordingly, the 10 farmer's fields were selected based on their willingness to handle the experimental fields. Before planting, surface composite soil samples were collected from the field for analysis at a depth of $0-20 \mathrm{~cm}$ in zigzag methods. Soil samples were collected using Auger. The collected surface soil samples from the experimental field were air dried, grinded and allowed to pass through $2 \mathrm{~mm}$ sieve for further analysis in the laboratory. The collected soil samples were analyzed for the parameters of $\mathrm{pH}\left(\mathrm{H}_{2} \mathrm{O}\right)$ in the suspension of a 1:2.5 soil to water ratio using a $\mathrm{pH}$ meter and Available P was determined by the Olsen's method using a spectrophotometer [14]. Then the farmer's field was selected based on the analyzed soil sample results in which the soil $\mathrm{pH}$ above 5.5 and available soil phosphorus below critical phosphorus (Pc) was selected for the experiments. 


\subsection{Experimental Design and Treatments}

The experiment was carried out on 10 farmers' field for two consecutive years. The experimental field was arranged with a total of 6 treatments with a randomized complete block design (RCBD) in three replications. The recommended Nitrogen $\left(92 \mathrm{~kg} \mathrm{ha}^{-1}\right)$ for the district was used. The gross plot size was $3 \mathrm{~m} * 4 \mathrm{~m}$ and the space between block and plot was $50 \mathrm{~cm}$. The net plot size was $2 * 2 \mathrm{~m}$. The required amount of seeds was weighed per plot by considering the recommended rate of wheat seed per hectare (150 kg ha ${ }^{-1}$ ). Urea, NPS, and DAP (Di ammonium Phosphate) was used as source of Nitrogen and Phosphorus containing fertilizers. Uniform field management practices for all plots were conducted. A bread wheat variety (Danda'a) was used.

The treatments were;

$$
\mathrm{T} 1=\text { Control (No fertilizer). }
$$

$$
\begin{aligned}
\mathrm{T} 2 & =25 \% \text { P-critical in NPS fertilizer }+ \text { Recommended Nitrogen } \\
\mathrm{T} 3 & =50 \% \text { P-critical in NPS fertilizer }+ \text { Recommended Nitrogen } \\
\mathrm{T} 4 & =75 \% \text { P-critical in NPS fertilizer }+ \text { Recommended Nitrogen } \\
\mathrm{T} 5 & =100 \% \text { P-critical in NPS fertilizer }+ \text { Recommended Nitrogen } \\
\mathrm{T} 6 & =100 \% \text { P-critical in DAP fertilizer }+ \text { Recommended Nitrogen }
\end{aligned}
$$

The determined P-critical value $(9.5 \mathrm{ppm})$ and phosphorous requirement factor (14.23) was used to calculate the rate of fertilizer to be applied. Thus, Phosphorus fertilizer rate was calculated by using the formula given below;

$$
\text { Rate of } \mathrm{P} \text { applied }=(\mathrm{Pc}-\mathrm{Pi}) * \mathrm{Pf}
$$

Where

Pc: Critical phosphorus concentration

Pi: Initial available $\mathrm{P}$

Pf: Phosphorus requirement factor which was derived from the calibration study.

\subsection{Data Collection}

Bread wheat grain yield was harvested at the ground level from the net plot area. Then, plant height was measured at harvest. After threshing, grain yield were cleaned and weighed.

Economic data such as production cost (input cost), gross income and net income based on the current market price of the yield and input was recorded.

\subsection{Economic Analysis}

Partial budget analysis was done to identify economical feasibility among. The average open market price (Birr $\mathrm{kg}^{-1}$ ) of bread wheat, price of fertilizers was used for analysis. For a treatment to be considered a worthwhile option to farmer, the minimum acceptable rate of return (MRR) should be $100 \%$ [4], which is suggested to be realistic. This enables to make recommendations from marginal analysis. Marginal rate of return (MRR) were calculated by using the formula given blow;

$$
M R R=\frac{\text { NetIncome FromFertilized Field }- \text { Net Income From Unfertilized Field }}{\text { Total Variable Cost From Fertilizer Application }}
$$

\subsection{Data Analysis}

All data recorded and collected were subjected to the procedure of analysis of variance (ANOVA) using R software program. The comparisons among treatment means were employed by using of Least Significance Difference (LSD) at $5 \%$ significant level.

\section{Result and Discussions}

\subsection{Soil Reaction and Available Phosphorus}

The soil $\mathrm{pH}\left(\mathrm{H}_{2} \mathrm{O}\right)$ of the study area was moderately to slightly acidic with the value ranged from 5.56 to 5.9 according to the ratings suggested by [15] (Table 1). Thus; the $\mathrm{pH}$ of the experimental soil was within the range for productive soils. The available phosphorus content of soils was low to medium with the value ranged from 7.24 to 10.39 ppm according to the rating given by [5]. Therefore, the soil of the study areas needs application of phosphorus containing fertilizers for crop production.

Table 1. Soil pH and Available Phosphorus of experimental field.

\begin{tabular}{lll}
\hline Site & Soil $\mathbf{~ p H}$ & Available P \\
\hline 1 & 5.59 & 7.87 \\
2 & 5.57 & 10.39 \\
3 & 5.90 & 8.18 \\
4 & 5.56 & 10.07 \\
5 & 5.66 & 7.24 \\
Average & 5.66 & 8.75 \\
\hline
\end{tabular}

\subsection{Plant Height}

Mean plant height was significantly $(\mathrm{P}<0.05)$ affected by NPS fertilizer rate. The highest $(94.56 \mathrm{~cm})$ plant height 
was recorded from the application of $100 \%$ P-critical in NPS fertilizer rate supplemented with recommended Nitrogen. The lowest $(63.62 \mathrm{~cm})$ plant height was recorded from control (without fertilizer) (Table 2). The result showed that plant height increased with an increased of NPS fertilizer rate supplemented by Nitrogen fertilizer (Urea). The increment in plant height might be due to increase in cell elongation and more vegetative growth attributed to different nutrient content of fertilizer containing NPS and the increasing of sulfur content caused a significant increase in wheat root and shoot growth as well as nutrient uptake. The sulfur deficiency results in stunted growth and reduced plant height [8]. This result is in line with results of $[1,12,16]$ reported that increased application of blended fertilizer significantly increased plant height of bread wheat.

\subsection{Grain Yield}

Grain yield of bread wheat was significantly $(\mathrm{P}<0.05)$ influenced by NPS fertilizer rate. The highest $\left(2833 \mathrm{~kg} \mathrm{ha}^{-1}\right)$ grain yield was obtained from the application of $100 \%$ P-critical in NPS fertilizer rate supplemented with recommended Nitrogen and the lowest $\left(888 \mathrm{~kg} \mathrm{ha}^{-1}\right)$ grain yield was obtained from unfertilized plot (Table 2). The results of this study indicated that, the mean of grain yield were increased with the increment of blended fertilizer rate. The highest grain yield at the highest NPS rates might have resulted from improved root growth and increased uptake of nutrients and better growth which enhanced yield components and yield of crops. This result is in agreement with $[3,7,16]$ who reported that, the maximum grain yield of bread wheat was recorded at the highest application of blended fertilizer rate.

Table 2. Effects of NPS fertilizer rate and recommended nitrogen on plant height and grain yield of bread wheat.

\begin{tabular}{lll}
\hline Treatment & PH (cm) & GY (kg ha $\left.{ }^{-1}\right)$ \\
\hline Without fertilizer & $63.62^{\mathrm{b}}$ & 888 \\
$25 \%$ P-critical in NPS fertilizer +Recommended Nitrogen & $90.66^{\mathrm{a}}$ & 2018 \\
$50 \%$ P-critical in NPS fertilizer + Recommended Nitrogen & $92.17^{\mathrm{a}}$ & 2238 \\
$75 \%$ P-critical in NPS fertilizer + Recommended Nitrogen & $92.25^{\mathrm{a}}$ \\
$100 \%$ P-critical in NPS fertilizer + Recommended Nitrogen & $94.56^{\mathrm{a}}$ \\
$100 \%$ P-critical in DAP fertilizer + Recommended Nitrogen & $92.80^{\mathrm{a}}$ & 2202 \\
LSD 0.05 & 6.56 & 2833 \\
CV\% & 11.55 & 2431 \\
\hline
\end{tabular}

Means with the same letter in columns are not significantly different at $5 \%$ level of significance's, $\mathrm{PH}=\mathrm{plant}$ height, $\mathrm{GY}=\mathrm{Grain}$ yield, $\mathrm{P}=\mathrm{Phosphorus}$.

\subsection{Partial Budget Analysis}

The partial budget analysis showed that the highest net benefit (53401.51 ETB ha $\left.{ }^{-1}\right)$ and the highest marginal rate of return (MRR) (1093.80\%) was obtained from the fertilizer application of $100 \%$ P-critical in NPS fertilizer with recommended Nitrogen fertilizer $\left(92 \mathrm{~kg} \mathrm{~N} \mathrm{ha}^{-1}\right)$. The lowest net benefit (17760 ETB ha ${ }^{-1}$ ) was obtained from unfertilized plots (Table 3). The MRR was indicated that bread wheat producers can get an extra of 10.94 ETB for 1.00 ETB investments in the NPS and N fertilizers application on the rates of $100 \% \mathrm{P}$-critical in NPS fertilizer with recommended nitrogen fertilizer $\left(92 \mathrm{~kg} \mathrm{~N} \mathrm{ha}^{-1}\right)$. Therefore, application of NPS fertilizer at the rate of $100 \%$ P-critical in NPS fertilizer with recommended nitrogen fertilizer $\left(92 \mathrm{~kg} \mathrm{~N} \mathrm{ha}^{-1}\right)$ for the production of bread wheat was more economically beneficial and recommended for Wachale district.

Table 3. Marginal analysis of bread wheat yield as influenced by NPS fertilizer supplemented by nitrogen rate.

\begin{tabular}{|c|c|c|c|c|c|c|c|c|c|c|}
\hline \multirow{2}{*}{ Trt } & \multicolumn{2}{|c|}{ Variable Input (Kg/ha) } & \multicolumn{2}{|c|}{ Unit price (ETB) } & \multirow{2}{*}{ TVC } & \multirow{2}{*}{$\begin{array}{l}\text { Output } \\
\text { (Kg/ha) }\end{array}$} & \multirow{2}{*}{$\begin{array}{l}\text { Unit price } \\
\text { (ETB) }\end{array}$} & \multirow{2}{*}{$\begin{array}{l}\text { Gross Income } \\
\left(\text { ETB ha }^{-1}\right)\end{array}$} & \multirow{2}{*}{$\begin{array}{l}\text { Net Income } \\
\left(\text { ETB ha }^{-1}\right)\end{array}$} & \multirow{2}{*}{ MRR (\%) } \\
\hline & DAP/NPS & Urea & DAP & Urea & & & & & & \\
\hline 1 & 0 & 0 & 0 & 0 & 0 & 888 & 20 & 17760 & 17760.00 & \\
\hline 2 & 35.48 & 185.35 & 12.5 & 10.5 & 2389.68 & 2018 & 20 & 40360 & 37970.32 & 845.73 \\
\hline 3 & 70.96 & 170.69 & 12.5 & 10.5 & 2679.25 & 2238 & 20 & 44760 & 42080.75 & 907.74 \\
\hline 4 & 106.44 & 156.04 & 12.5 & 10.5 & 2968.92 & 2202 & 20 & 44040 & 41071.08 & 785.17 \\
\hline 5 & 141.92 & 141.38 & 12.5 & 10.5 & 3258.49 & 2833 & 20 & 56660 & 53401.51 & 1093.80 \\
\hline 6 & 117.24 & 154.12 & 12.5 & 10.5 & 3083.76 & 2431 & 20 & 48620 & 45536.24 & 900.73 \\
\hline
\end{tabular}

Where: Trt $=$ Treatment, TVC $=$ Total Variable Cost, MRR $=$ Marginal Rate of Return.

\section{Conclusion and Recommendation}

The productivity of wheat is declining e due to many reasons and among the low soil fertility is the most one. With the objective of solving this soil fertility problem, soil test crop response based fertilizer rate recommendation has been conducted across the country. The grain yield of bread wheat was influenced by NPS fertilizer rate whereby the results of this study clearly indicated that, the mean of grain yield were increased with the increment of NPS fertilizer rate. In addition, partial budget analysis has also shown a variation among the treatments and depicted that, application of NPS fertilizer at the rate of $100 \%$ P-critical in NPS fertilizer with recommended Nitrogen fertilizer $\left(92 \mathrm{~kg} \mathrm{~N} \mathrm{ha}^{-1}\right.$ ) for the production of bread wheat was more economically beneficial 
and recommended for Wachale district.

Therefore, demonstration and further scale up of soil test crop response based phosphorus fertilizer recommendation with $92 \mathrm{~kg} \mathrm{ha}^{-1}$ of Nitrogen demonstrated and further scaled up for bread wheat in Wachale district could be recommended and also the farmers could be used 100\% NPS fertilizer rate in relative to determined critical phosphorus for bread wheat in the district.

\section{Acknowledgements}

The authors would like to thank Oromia Agricultural Research Institute for financial support and Fitche Agricultural Research Center for providing all the necessary facilities required for the research.

\section{References}

[1] Abebaw Tadele and Hirpa Legese, 2018. Effects of Fertilizer Rate (Blended) and Sowing Methods on Yield and Yield Components of Bread Wheat (Triticum aestivum. L) in Western Ethiopia. International Journal of Compressive Research and Biological Science. DOI: http://dx.doi.org/10.22192/ijcrbs.2018.05.06.001.

[2] Assefa M., Johnson M. R. Semoka, N. A. and Tekalign M. 2015. Wheat Response to Applied Nitrogen, Sulfur and Phosphorous in three Representative Areas of the Central Highlands of Ethiopia. International Journal of Plant \& Soil Science, 8 (5). pp: 1-11.

[3] Bizuwork Tafes. 2018. Growth, Yield and Grain Quality of Durum Wheat (Triticum turgidum L. var. durum) as Influenced by Rates of Blended NPSB and N Fertilizers at Debre Zeit, Central Ethiopia. MSc Thesis, Haramaya University.

[4] CIMMYT (International Maize and Wheat Improvement Center). 1988. From agronomic data to farmer recommendation: An Economic work Book. Mexico, D. F.: CIMMYT.

[5] Cottenie, A. 1980. Soil and plant testing as a basis of fertilizer recommendations. FAO Soil Bulletin 38/2. Food and Agriculture Organization of the United Nations, Rome, Italy.
[6] CSA (Central Statistical Agency). 2019. Agricultural sample survey. Report on area and production of major crops (private peasant holdings, meher season). Addis Ababa, Ethiopia.

[7] Diriba Shiferaw G, Rut-Duga D and Wogayehu W. 2019. Effects of Blended Fertilizer Rates on Bread Wheat (Triticum Aestivum L.) Varieties on Growth and Yield Attributes. Journal of Ecology \& Natural Resource, 3 (3): 000170.

[8] Doberman, A. and Fairhurst, T., 2000. Nutriments Disorders and Nutriments Management. International Plant Nutrition Institute.

[9] EthioSIS (Ethiopian Soil Information System). 2013. Soil analysis report. Agricultural Transformation Agency (Unpublished).

[10] FAOSTAT. (2014). Online [Internet]. Retrieved August 6, 2020, from. http://faostat.fao.org/site/291/default. aspx. FAO, Rome.

[11] Hillette Hailu, Tekalign Mamo, R. Keskinen, E. Karltun, Heluf Gebrekidan and Taye Bekele. 2015. Soil fertility status and wheat nutrient content in Vertisol cropping systems of central highlands of Ethiopia. Agriculture and Food Secure. 4, pp: 19-23.

[12] Melesse H. 2017. Response of bread wheat (Triticum aestivum L.) varieties to $\mathrm{N}$ and $\mathrm{P}$ fertilizer rates in Ofla district, Southern Tigray, Ethiopia. African Journal of Agricultural Research 12 (19): 1646-1660.

[13] Minot, N., Warner, J., Lemma, S., Kasa, L., Gashaw, A., \& Rashid, S. 2015. The wheat supply chain in Ethiopia: Patterns, trends, and policy options. International Food Policy Research Institute (IFPRI).

[14] Olsen, S. R., Cole, C. V., Watanabe, F. S. and Dean, L. A. 1954. Estimation of available phosphorus in soil by extraction with sodium bicarbonate. USDA circular 939: pp 1-19.

[15] Tekalign Tadese. 1991. Soil, Plant, Water, Fertilizer, Animal Manure and Compost Analysis. Working Document No. 13. International Livestock Research Center for Africa, Addis Ababa, Ethiopia.

[16] Tilahun Abera and Tamado Tana. 2019. Growth, yield component and yield response of durum wheat (Triticum turgidum L. var. Durum) to blended NPS fertilizer supplemented with $\mathrm{N}$ rates at Arsi Negelle, Central Ethiopia. Vol. 13 (1), pp. 9-20, January 2019. 